\title{
The Other Frankfurt School
}

\author{
Mark P. Worrell
}

As director of the Institute of Social Research ("Frankfurt School”), Max Horkheimer led an exodus of radical scholars across Europe and the Atlantic, cultivated rich networks of international support, oversaw important research projects, and authored or oversaw the production of some of the most influential, scholarly texts of the twentieth century. And as the leader of an organization with financial resources Horkheimer extended a lifeline to numerous scholars desperately in need of assistance. [1] Yet, his relationship toward the Institute (ISR) was complicated upon arrival in the United States and it led, over time, to a decisive rupture between the so-called "inner circle" and the "dispersed forces" of critical sociology working along the periphery of the Institute.

Zoltán Tar (1984) portrays the Institute's path under the direction of Horkheimer as a gradual transition away from Marxism toward a bleak cultural critique that found its expression in works such as Eclipse of Reasonand Dialectic of Enlightenment (p. 7). While this is true, the Frankfurt School was no "solid crystal" and there were elements within the Institute that vigorously resisted this pessimistic turn (Scheuerman 1994). The dialectics project was attractive to Horkheimer because it held out the prospect of dissolving all but the core members (Horkheimer, Pollock, Adorno, Lowenthal, and Weil) [2] and living off the Institute's limited resources whereas the anti-Semitism project offered a large-scale, funded, empirical research agenda that continued the Institute's mandate to investigate the social psychology of the working class and the dynamics of authoritarianism. The anti-Semitism research stream was, I argue, the heart and soul of the Institute's critical social theory during this period. To abandon it would mean, essentially, the abandonment of critical theory itself: the interrogation of class, character, capitalism, and domination. But the trajectory of the inner circle was driven by contradictory forces, warping its relationship to the outside world including its treatment of peripheral members: the disintegration of the Popular Front; the fear of being ensnared in anti-communist harassments both real and imagined; financial stresses; [3] the group's ambivalent integration with Columbia University; external funding and constraints from Jewish defense organizations (e.g. AJC and the JLC); geographical separations; the moral imperative to assist European refugee scholars; and personal psychology. [4] Ultimately, the dialectics project took priority over much of the anti-Semitism research, including the labor study, to the detriment of critical sociology.

\section{Dialectic of Enlightenment}

Kellner calls Dialectic of Enlightenment "a genuine turning-point" whereby the Frankfurt School "abandoned the earlier program of interdisciplinary social theory and immanent critique" (1993:48; cf. Tar 1984:7) and critics have, over the years, bemoaned its incoherence and irrationality. Whereas Dialectic is famous for phrases such as "enlightenment is as totalitarian as any system" and "in the service of the present age, enlightenment becomes wholesale deception of the masses" ([1944/47] 1972:24, 42) the book is not without its substantive virtues and intriguing suggestions such as, to name only a few: (a) economic exchange and modern, industrial labor processes represent transfigured and extended analogs of the premodern ritual production of sacred forces; (b) the emergence of a politics of domination and exploitation with the mobility of the totemic emblem and the personification of mana; (c) anti-Semitism as a conscious tool in class warfare; (d) the symbol of the Jew as a condensed representation of capitalist excesses and a distorted representation of class relations and dynamics; and (e) anti-Semitic propaganda as an element in the organic composition of capital to exploit, further, the variable (social) limits of living labor, etc.

However, in the final analysis, Dialectic suffers immeasurably from reductionism, simple antisociology (witness 
the clumsy deployment of the mana concept in chapter one where animism, naturism, and realism collapse into an undifferentiated heap), irresponsible sloganeering, and bewildering leaps across time and space that would have made the Poughkeepsie Seer blush. Ultimately, Dialectic did not prove to be a temporary detour for Horkheimer and some of his unpublished articles and lectures of the same period make its pessimism pale by comparison and are even more disturbing in their proposals for concrete action: for instance, Horkheimer's heretofore unexamined "Academy" article where he called for, essentially, an educational dictatorship of philosopher kings (Europe's "cream") to lord over the rabble. No, by the mid-1940s, like many former leftists, he was well on his way out of the critical theory business. [5] One problem, though, was that the Institute was populated by many who still held commitments to the left and to labor and it meant an eventual collision. If Dialectic was, as Kellner says, an intellectual "turning point" it also represented a rejection of political and ideological projects that would have made sense to labor communists and CIO radicals who pioneered the struggle against racism and injustice just ten years before. The Berkeley study, for example, was made liberal-friendly (and was still ruthlessly attacked upon publication) but the labor study was a different animal altogether, and rinsing the Marxism out of it would have been difficult if not altogether impossible; it appears that, from Horkheimer's position, it was preferable to rinse the Marxism out of the Institute itself.

\section{| The Closing of the Popular Front: Anti-Communism, and the Flight from Critical Theory}

Virtually every scholar who has examined the wartime, organizational dynamics of the Institute has accounted for the ever-shrinking nature of the so-called inner circle on the basis of: (a) the growing philosophical pessimism of Horkheimer and his desire to exist in a state of "splendid isolation"; (b) the dwindling financial resources of the organization, necessitating an unloading of "ballast" such that Marcuse and Neumann, among others, were literally pushed away from the Institute and toward external sources of income, such as the O.S.S.; and (c) the inner circle's drift toward a theory of state capitalism, away from the stubborn orthodoxy of many of the peripheral members such as Neumann, Gurland, Massing, to name many.

I think these interpretations are true but incomplete, as they tend to emphasize intellectual and organizational aspects while neglecting the purely political. Horkheimer did grow increasingly pessimistic over time and he undoubtedly felt little dependency on an empirical data apparatus for the production of his abstract philosophy; from the research on authority and family to Dialectic he demonstrated a bewildering lack of contact with empirical evidence. And the move toward a theory of state capitalism was not merely arrived at through reasoned analysis but a response to the unrepentantly Marxian analyses coming out of the ISR's outer rings. Whatever the inner circle's stance toward communism, socialism, and Marxism had been prior to fleeing Germany, it seems obvious that, like many other former radicals, the core group arrived at a general rejection of radical thought and, more importantly, feared that the assorted research associates and assistants that populated the Institute (Massing, Gurland, Neumann, Kirchheimer, Marcuse) would literally drag them down into a political morass or worse, result in their deportation from the United States. Oddly enough, the threat may have been real to a certain extent.

The Institute became a domestic surveillance issue in July 1940[6] when Grossmann fell under suspicion of the authorities of Provincetown, Massachusetts of being a Nazi spy: "This man has been on Cape Cod for the past few days and has all kinds of data regarding the location of harbors. Most of the data has to do with Provincetown. It is believed that part of his identification is phoney [sic] and is being checked with Fifth Column activities..." (FBI MH). For the next year, off and on, the Institute was under investigation by the FBI, suspected of operating as German intelligence agents until, in the Fall of 1941, an informant at Columbia fingered Weil, Gurland, and Wittfogel as Soviet agents and characterized the Institute as a Comintern front organization. [7] In August 1943 Gumperz, the individual most responsible for getting the ISR to the United States and who negotiated the Institute's working relationship with Columbia University[8] was briefly arrested for taking photographs near a military installation on Long Island. Frank Fackenthal, Provost of Columbia University, vouched for Gumperz and the Institute, assuring the Bureau that the their outstanding features were, in the case of Gumperz, that he "spoke the German language" and, in the case of the Institute, that it generated "a lot of waste paper" (FBI MH). Whatever the real or imagined connections between Gumperz and Soviet intelligence, there were operatives working within the Institute.

It is widely known that Paul and Hede Massing were, at one time, Soviet intelligence agents. Paul, in his own accounts, claimed that he briefly assisted what he believed to be a Red Army intelligence unit in Europe and Hede became famous in the late 1940s for her role in the Alger Hiss/Whittaker Chambers/Noel Field affair-all of which 
was recounted in her 1951 book This Deception. They both maintained, and to the best of my knowledge their claims have never been challenged, that they were out of the espionage business by 1938. Paul Massing's testimony in front of the House Un-American Activities Committee also portrayed the couple as out of the intelligence game by 1938. [9] But, as it turns out, their involvement went at least into the summer of 1944 (Weinstein and Vassiliev 2000:250). [10]

Hede ("Redhead"), Paul ("Vatsek"), and Franz Neumann ("Ruff"), all Institute associates or, in the case of Hede, wife of an associate and a temporary research assistant working on the labor study (employed at the AJC while Horkheimer was the research director), were all operatives within the "Redhead Group." [11] Additionally, Stephen Duggan, the father of famed Soviet spy Laurence Duggan, was a member of the ISR's advisory board and officer of the Emergency Committee that helped to fund some Institute salaries; the ISR, especially, Adorno was tainted by the unfolding of the high-profile Eisler affair- the FBI documented frequent telephone communications between Hanns Eisler and Adorno between December 1946 and March 1947 as Gerhart Eisler was under threat of deportation (see Wiggershaus 1994:389-91 for background); Pollock, Horkheimer, and Adorno were under suspicion of providing sympathy and material support for Ruth Fischer (one of the former leaders of the German KPD and sister to the Eisler brothers); and much to the chagrin of the director, Marcuse continued to tout a very orthodox, Party-approved tone as late as 1947. What did Horkheimer know and when did he know it? This is unclear but only the most naive interpreter could believe that Horkheimer wasn't sufficiently aware of, and frightened, by the stubborn radicalism within the Institute's ranks such that he felt compelled to either unload them or seal them off from the inner circle.

The purge trials of 1937 and 1938 marked the beginning of the end for the anti-fascist Popular Front—events that made it impossible for many fellow travelers to remain faithful in the Soviet experiment. And the Nazi-Soviet Pact of 1939 truly rocked the American Left resulting in a mass exodus of radicals and fellow travelers. A letter from Granville Hicks to Joseph Freeman, future research and editorial assistant for the Institute, was representative of the shock: "This is a very difficult letter for me to write. I have been deeply disturbed by the Soviet-German pact. There is no sense in my explaining what troubles me, for you and everybody else must know. The only thing that is necessary for me to say is that at the moment I find it utterly impossible to defend..." (GHb21f Freeman 193958). Of course, the pact of 1939 was short-lived and the Soviet Union was an official ally during the war but few returned to the fold and by the mid-1940s the problem of political identity was acute. If Horkheimer wanted to keep a low profile[12] while in America, the Institute, literally abuzz with radicals, former radicals, suspected radicals, and recovering radicals, were definitely a source of potential problems and I think that this, as much as the problem of subjective propensities or philosophies, was an important factor in shrinking the inner circle and the desire for "splendid isolation."

These political tensions came to a head toward the end of 1944, right in the middle of the labor study fieldwork, when Massing and Gurland (the two principle authors of the study) appealed to Horkheimer for what they perceived to be Lowenthal's cowardly deviation from the Institute's program. The director blasted back on October 5th, in no uncertain terms, that, on the contrary, it was Massing and Gurland who were the deviants (LLbMSGer 185). [13] Likewise, the labor study itself had become a kind of deviant project; as the political horizon contracted, the labor study and kindred projects receded from sight. At the minimum, the labor study represented, arguably, a jewel in the Institute's crown, a landmark study that truly fused empirical research with theoretical development, and one that tied the ISR's American exile period to its earlier, milestone project on the Weimar proletariat and the work on authority and family. However, as fate would have it, the study would never see the light of day.

\section{The Labor Antisemitism Study}

A large-scale study of workers was familiar territory for the Institute. Between 1929 and 1931 the school had undertaken a pioneering study of the Weimar proletariat (finally published in 1984 as The Working Class in Weimar Germany). In his summary of the project, Smith (1998) states:

The overall results were disturbing. On the one hand, for a fair number of left-wing respondents, there was "a far-reaching accord between personality and party program. These people wanted freedom, equality, and happiness for all: they hated war and sympathized with the oppressed. Their convictions and commitment were passionate and strong." This was Fromm's 
Revolutionärer group. Others, however, were Ambivalenter — and still others were largely authoritarian....For many German workers...there was a serious "discrepancy" between political beliefs and character....Careful sifting of the data yielded the conclusion that only 15 percent of the KPD and SPD members were genuinely radical personalities-while 25 percent were either potentially or primarily authoritarian. (Pp:68-69)

In other words, the German working class was emotionally unreliable and could not be counted on to repel an authoritarian onslaught. Yet this survey, as important as it was in not only the Institute's history but for the development of the empirical social sciences in general, was less a programmatic fulfillment of the Institute's multidisciplinary and critical agenda and more of a "good start." [14] The Weimar proletariat study reappeared in its sublated form as a moment within the massive and quasibrilliant Autorität und Familie report. But, here too, the 1936 publication (portions of which were translated into English and republished in 1937 under the partial auspices of the social science department at Columbia University) failed to deliver the promised integration of empirical data, multidisciplinary analysis, and theory formation; the theoretical contributions failed to establish a substantive connection with the empirical evidence in the rest of the study: "The fact that the theoretical drafts did not refer at any point to the questionnaire material or to the reports on research and literature dramatically illustrated the limited extent to which a 'fusion of constructive and empirical procedures' could be spoken of" (Wiggershaus 1994:151). Additionally, the problem of anti-Semitism had yet to materialize in the Institute's work as it would after the move to the United States. [15] One could cynically argue that the ISR only undertook the anti-Semitism project because of funding opportunities offered by organizations such as the AJC. Yet, I think this view would be overly simplistic. The Institute's earlier work on authoritarianism had failed precisely on the grounds that it could not sufficiently ground the problem in the larger dynamics of capitalist society. Only later did they come to comprehend the importance of "the Jew" for unraveling the hieroglyphics of bourgeois-liberal society [16].

Dubiel ([1978] 1985) claims that the labor anti-Semitism project was "conceived by Max Horkheimer" but it was actually Franz Neumann's idea (p. 195). Horkheimer, though he was excited about the overall program on antiSemitism, was opposed to the labor study in particular and, as Wiggershaus indicates, felt that it was an unwarranted intrusion: "Horkheimer wanted, if possible, to drop the sub-project arranged by Neumann on anti-Semitism in the working class. He saw this as an unauthorized addition by Neumann to the draft of the project which had been published in SPSS. 'By the way,' he mentioned to Pollock, this idea of a survey on the whole of the labor movement, just to find some anti-Semitic reactions, is, in my opinion, scientifically ridiculous"' (Wiggershaus 1994:355). Besides, as Horkheimer stated in a November 8th, 1942 letter to Neumann, the labor study was pointless insofar as labor did not represent a "hot-bed" of anti-Semitic trouble (LLbMSGer185). Nonetheless, Neumann's idea was attractive to the AJC and the JLC who decided to fund the study.

The labor study examined three main areas of anti-Semitic hostility:

Area I. Supposed Jewish Personal Traits
A. Clannishness
B. Aggressiveness
C. Sexuality (deviance)

Area II. Jewish Economic Practices
A. Jews in business and Jewish control over business
B. Jewish mercenary attitudes and money-mindedness
C. Jews as anti-workers

Area III. Jews and Politics
A. Jews have too much power
B. Jews, education, and excess privilege
C. Weak Jewish war effort

Here, I will briefly examine a few dimensions of "Area II": supposedly Jewish Economic Practices followed by a summary of all three "Areas." [17]

The authors of the labor report were Gurland (Part One and Two), Massing (Part Three and Six), Lowenthal (Part Four), and Pollock (Part 5). For now I will not concern myself with the fourth or fifth parts. Lowenthal's 
portion was published in a completely rewritten form in 1987 and Pollock's contribution dealt only with labor leaders and union officials. The central parts of the report were those sections authored by Gurland and Massing who, combined, were responsible for exactly $75 \%$ of the completed report. [18]

The findings of the labor project were, on the surface at least, horrifying and dramatically undermined Horkheimer's earlier assumptions regarding labor prejudice. The ISR found that the interviewed workers possessed zero capacity for radical thought and, much to their surprise, discovered that roughly $21 \%$ of the workers were extreme authoritarians and virtually Nazi sympathizers (10.6\% were classified as "exterminatory" and another $10.2 \%$ felt "intense hatred" for Jews but fell short of openly calling for the extermination of Jews). Ultimately, one half of the workers (566 AFL, CIO, and unorganized workers interviewed in New York, Los Angeles, Detroit, and Philadelphia) were debilitated to one extent or another by anti-Semitic beliefs. In the view of the ISR, anti-Semitism represented, as they called it, the "spearhead of fascism" and they wanted to know if the vaunted CIO was ready to repel authoritarianism on the domestic front. The answer appeared to be an unqualified "no" but, upon further analysis, the issue was not so cut-and-dry.

Gurland and Massing found deep variations along ethnic, educational, gender, and religious lines. Their ideal typical anti-Semite was:

Male; 50 or older; Italian; Catholic (infrequent church attendance); possessing less than a high school education; a menial laborer-at the bottom of the job ladder, low occupational status; and had not been "Americanized" (i.e. had not been transformed by the American experience due his or his family's recent arrival in the States).

Their worker who was ideal typically resistant to anti-Semitism was quite different:

Female; in her 20s; descended from White, Protestant, Northern European stock; either actively Protestant or nonreligious; possessing either a high school degree or some college experience; and was fully "Americanized."

They also found that white-collar workers were "amazingly liberal" in contrast to their European counterparts. Blacks and Hispanics also emerged from the study as being relatively free from the worst kinds of anti-Semitism. The labor report postulated that the future of American labor was heading, decisively, away from authoritarian ideology and that important segments of the working class were resistant or allergic to anti-Semitism.

The research was scheduled to be published along with its sister project that culminated in The Authoritarian Personality but it was shelved instead (Adorno et al.1950; see Jay [1973] 1996:225). (The only publication that bore any relation to the labor study was the little foam bubble Labor's Enemy: Anti-Semitism (1945) by Charles Sherman of the JLC that does not warrant further analysis here. In Martin Jay's (1996) classic history of the Institute, Pollock is relied upon to make the following assertion: "the conclusions of the study were so damaging to American labor that the Institut, with its characteristic caution, was hesitant about broadcasting its findings" (p. 225). However, it was not really the case that the labor study would have been the wrong book at the wrong time in the broadest terms, but, rather, the report's findings dramatically challenged the assumptions of Horkheimer's dialectics project and even undercut some of the theoretical inconsistencies of the Berkley study. While mildly damaging to labor, at least in a superficial ways, it represented a far greater threat to the bourgeoning anti-dialectical pessimism of Horkheimer and his inner circle, which was quickly jettisoning their Marxist baggage. In short, Gurland and Massing delivered solid, critical, sociological interpretations of their data grounded directly in the logic of capital accumulation and life in capitalist society whereas Horkheimer and Adorno weaved erratically between abstract philosophy and orthodox group psychology.

Gurland was responsible for exploring the anti-Semitic hatred of supposedly characteristic Jewish commercial and business practices. His interpretations clearly avoided the type of frequent reductionism found in Dialectic where Horkheimer and Adorno report that, among other things, "The penetrating and distant gaze, the hypnotic and the disinterested look, are of the same type; in both cases the subject is extinguished. Because such gazes lack reflection, those who do not think are electrified by them" (1945:191). One cannot "think with" or "through" such notions as they represent the negation of social theory in general, as Horkheimer and Adorno themselves admitted: they closed out the chapter on anti-Semitism by claiming that "contemporary anti-Semitism...[is] impenetrable [and] meaningless...The Jewish go-between is turned into a devilish character after he ceases to exist in the economy" (1945:206). "Devilish character" aside, these kinds of conclusions were incommensurate with the findings of the "other" Frankfurt School and, really, mind-bogglingly stupid. But rather than rehashing the line of thinking found in Dialectic let us explore, and think through, the kind of reasoning delivered up by Gurland and Massing in the labor 
report.

The most elementary answer to worker resentment toward "Jewish" business practices, resided, according to Gurland, in the fact that "Perfectly normal business procedures appear as illegitimate because they strikingly differ from those which regulate the sale of the worker's labor power" (AL:367). Simply put, buying and selling bread and milk at the corner shop (before or after work) deviated from the logic of buying and selling of human time and energy (during work). It is worth quoting at length here:

The worker is not in a position to overcharge anyone, especially not his customer, the employer to whom he sells his hands. Logically he resents those who overcharge him. He feels victimized by the storekeeper. He knows when he looks for a job or has accepted work he cannot change the price of what he has to sell, his labor power. Neither can he substitute a cheaper brand for his particular merchandise. Wage rates, efficiency standards, piece rates usually are fixed under contract for a definite length of time. There is no collective bargaining to negotiate a contract with the retailer.

With the employer who buys his labor power the worker deals collectively. With the storekeeper from whom he buys the necessities of life he has to deal as an individual. His wage problem is taken care of by the union, the collective representation of his interests as a seller. His shopping problem is not taken care of by anyone....

It has been shown before that the Jew as a rule is being identified as a retailer, merchant, [and] storekeeper. Now, this "trader" cheats the worker out of what he has earned through hard work in the factory or plant. The easiest conclusion is that the Jew is dishonest and has to be considered the principal enemy of the worker. (AL:366-67)

The "Jewish" store owner represented "an evil outgrowth of a system which he does not suspect of normally, constantly and legitimately employing such procedures for coordinating market operations” (AL:366). In short, we find that worker anti-Semitism was less about chafing against capitalist alienation and exploitation in the abstract sense and more about the abhorrence of contingent alienation and the impenetrable mystery of the value-price relation. The "Jew" marked not merely exploitation but random, arbitrary, and unverifiable (if "intuited") exploitation. Workers were willing to be alienated as long as the system promised the appearance of fixed, routine, and nonrandom operations (even though it is obvious that the capitalist mode of production is defined by its exploitation of variable capital that is, labor power, and punctuated by periodic ruptures, or better, the periodic destruction of routines and fixed order. The "Jewish" store owner was a metaphor for the abyss of contingency (the market where "anything goes") where the disorder of capitalism offered regulated islands in time and space where workers could cling to the fiction of self-determination and autonomy. New Deal "sops and lures" really were psychological miracles for workers unable to conceptually seize hold of class relations and ripe for antisemitic propaganda due to their limited and contradictory nature-"the Jew" appears in the very limits of the various New Deal programs:

The situation is felt particularly strongly because the worker's attention is centered on how he spends his weekly pay much more than on what his pay is. Through the last ten years wage standards have considerably improved under the codes of the early New Deal, under collective bargaining, under the Wagner Act with its provisions on union recognition and mediation. Improvement of wage rates has eased to be the worker's individual affair. As for prices and bargains, they still are the workers individual, personal affair. He cannot rely on any organization to help him settle these everyday problems (ibid.).

Can we say that anti-Semitic workers were hostile to capitalism? I think the matter is better grasped as Ambivalenz: simultaneously attractive and repellant, a thing of awe, wonder, love, hate, disgust, and horror. Workers prone to antiSemitism were, I think, willing to set aside their selves to acquire order and regulation where, relations where personal responsibility is lifted and assumed by higher authority, and where burdens are universally shared (the "rewards" of alienation qua recognition, normality, counting, in short, to make a normal appearance in the social/public realm). For the anti-Semitic worker, it was precisely the abnormal, excess, and lack that needed to be eliminated.

Higher prices for goods were not a problem as much as the lack of uniformity of prices and the ability to cheat the system, to wheel and deal, buying and selling on the black market (i.e., the realm of the Jewish). The "Jew" signified the cracks in the system, exceptions to rules, and disorder on the margins of apparent order. In a way, the "Jew" marked the refutation to systematic alienation and exploitation whereby the individual could circumvent or short-circuit the normal operations of the system. And, clearly, it was both the resentment of that ability to shortcircuit the system and the simultaneous desire to short-circuit the system. At the same time, though, the hatred of the Jew was a confused recognition that the normal operations of the labor contract were set up to cheat workers:

He is skeptical with respect to price enforcement by government agencies because he thinks OPA officials are either lazy bureaucrats who live on his, the taxpayer's money or shyster lawyers who represent the interests of those whom they ought to 
be watching all the time. His attitude to rationing and price control is dictated by the idea that dealing with his storekeeper individually, on a personal basis, he would fare better. In practice, he constantly encourages the "unethical" procedures of which he complains (ibid.).

We can say that anti-Semitism is so complex and contradictory because social processes and institutions are complex and contradictory. The spectral Jew and the chain of signifiers that orbit around the Jewish nucleus are tantalizing if ridiculous ways of thinking about society and social contradictions. In the mind of the anti-Semite it is the other way around. Social processes and institutions, in all their bewildering complexities, are merely instances of the Jew and "the Jew" was not an explanation of inexplicable supernatural events or mysteries. On the contrary, "the Jew" was the personification of structures and processes that seemed perfectly obvious to the anti-Semite. Whereas Horkheimer and Adorno simply threw up their hands and declared that the phenomenon was an impenetrable mystery, Gurland (here, just a couple of pages of the labor report were quoted for example) theorized, and allows us to theorize with him, the riddle of the value-price dialectic, the foundational and socially constitutive nature of alienation, the buying and selling of labor power, and commodity fetishism.

Some of the major themes and findings of the ISR's labor report and some of the main interpretations (in respect to all three areas) are as follows:

- The anti-Semitic response to Jewish "clannishness" revealed something about the authoritarian ambivalence toward solidarity and collective relations. Anti-Semitic workers were less anticollective or antigroup per se than they were opposed to democratic and plastic forms of cohesion and identification. Supposed clannishness was in a sense a way for workers to beat down a (positive) relationship of spontaneity and latitude and to erect, in its place, an ideal of hierarchy and static placement within a stable, durable, predictable social order under the sign of the legitimate leader. For the authoritarian, life "inside" the group was one of obedience and alienation whereas life "outside" the group was mere contingency. One prevented the descent into chaos by ritually and vigilantly maintaining rigid order within the group. Once depersonalization was allowed to dissolve within the group chaos was sure to creep in. For this reason "groups" were automatically suspect at some level: they were fine for nonvital activities but when it came to anything serious, group solidarity might not be strong enough to suppress the tendency to devolve into a breakdown of order and lose one's place within social organization.

- Jewish "aggressiveness" was, ironically, a way for anti-Semitic workers to attack Jews for their perceived unwillingness to submit to the dictates of collective life. Jews were, they felt, "too good" to be a part of the group. This individualism led them to be weak and vulnerable so they overcompensated by being aggressive toward others. So, for the authoritarian, there was safety in numbers - the "herd" (the gray, undifferentiated mass of workers, each in his or her place, under the watchful gaze of embodied power) provided cover and security. If one wanted security one had to sacrifice a good many things such as individual freedom. The anti-Semite's motto is: "will to power"-that self-conquering impulse infused with ascetic, expiation explored by Nietzsche (as well as Durkheim and Weber).

- Many aspects emerge from the "Jews in business" section: for one thing Jews represented frustrations and breakdowns in the normal flow of commodities such as rationed goods. Workers suspected that some groups had privileged connections and monopolized cigarettes and liquor. Secondly, Jews symbolized not exchange per se but the mysteries and excesses of exchange-especially the felt but incomprehensible divide between prices and exchange values. The "Jew" was a sign of divergences and contingent fluctuations in prices above and beyond values. Here, again, the Jew was "too much" or "not enough"- exploiters and undersellers. Hence, Jews controlled "all" stores and preferred loans and credit to hard, legitimate work. Jews, it was thought, willingly sought to operate on the margins of economic life as parasites who avoided hard work and who derived a perverse pleasure in getting something for nothing.

- Nearly $80 \%$ of anti-Semitic workers complained about the supposed "mercenary" spirit of Jews and this emphasis on profiteering served to focus and condense hostility into a more narrow conception of Jews in society. Here the "Jews as mercenaries" idea boiled things down to money and the various schemes Jews concocted to extract money from non-Jews. The schemes ran the gamut from simple and petty rip offs to manipulating the government, markets, and orchestrating the entire war. It was with the notion of profiteering and mercenary spirit that the "everything" of antiSemitism was able to establish a gravitational center around money-or, really, excess money. When workers were able to identify the profiteering motives of Jews they were capable of retroactively recasting all Jewish activities and even personal traits such as clannishness and filth as means and secondary formations around the rapacious and "stop short of nothing" mentality of the imaginary Jew. Literally, the formula for much of the Jewish relation to money (in chapter four) was: "Jews running around Washington cashing in on the war."

- The "Jew as worker" was an exceedingly complex problem and pointed to many aspects of workers and their relation to authority, work, the buying and selling of labor power, the split between prices and values, the value-form that their labor power assumed, the nature of the labor process, the normative aspects of work intensity and the implied worker "code" that determined their stance toward making demands against capital for more of a share of the surplus. Jews 
were seen as a corruption of the imaginary, unmediated relation between the worker and the entitled boss who stood in the reflected glory of and received legitimation from the myth of the genius entrepreneur. The Jew was an alien intruder that degraded the dignity of the skilled (and unskilled) worker who knew and respected his or her "place" within the hierarchic work order. Jews were felt, by anti-Semites, to be biologically incapable of real work and, if they were found on the shop floor, were "slumming" to avoid the draft. In other words, Jews were essentially identical to "buying and selling" (junk, liquor, cigarettes, cheap clothes, etc.) but they were incapable of merely selling (i.e., being the individual possessing only one commodity to sell: labor power).

- Jews were felt by many anti-Semitic workers to have an unnatural and perverse relationship toward power: they wanted it all for themselves rather than share it. Of course, for the anti-Semite, their desire was generally to see Jews divested of all power and redistributed, presumably, back into the world of non-Jews. But, we must observe, here, that the data did not generally support any widespread belief that Jews were the demonological masters of the universe; "the Jew" was not quite the key to all the mysteries of the cosmos in the way it was in European and Nazi propaganda. However, anti-Semitic workers still deployed a universalizing language of "all" and "every" when speaking of Jews. But it was not in the sense that Jews controlled all political power. In that case it was that Jews gravitated and migrated to Washington because that was where the soft jobs were. Jews could infiltrate government bureaus and boards to make life easier for themselves and other Jews (quite unlike the Nazi interpretation or the fantasies of contemporary rightwingers that see the Jews as part of a New World Order where the United Nations is but a screen for Jewish world domination. The notion, for example, of a Zionist Occupation Government (Z.O.G.) would have been quite unreal and unconvincing for most of the workers in the Institute's study. Jewish "power", quite simply, meant the control of business and banking. Though, it should be pointed out, some anti-Semitic workers thought that what Jews were able to achieve in Germany was something quite distinct from their power in America. Some were willing to believe that Jews really did represent a total social menace in Germany (hence, the necessity to exterminate them all) while simultaneously believing that Jews had limited powers in the United States. In a sense, many workers felt that America was simply bigger and stronger than the Jews and could resist the kind of effects that Jews had on Germany while others worried about the power of Jews to furrow deeper into American life and eventually gain the upper hand on non-Jews: what the Nazis did might have to be replicated in the United States!

- Jews were felt by anti-Semitic workers to have an unnatural affinity for education and intellectualization. Their "brain power" went with their inability, avoidance, and antipathy toward manual labor. Jews "had to" get more education because they could not do real work and Jews used education to make more money doing far less than real workers. Education was the best route to exploit others and make excessive money. Jews were seen as unnaturally overrepresented in the fields of medicine and law. They monopolized the field of necessities-the sick worker had to go see the Jew. The worker who got into a scrape with the law had to pay the Jew. In this way any time a worker moved beyond the parameters of work they entered the nefarious web of Jewish appropriation and exploitation.

- $\quad 30.7 \%$ of workers sampled were considered to be anti-Semitic by the ISR. Of that group $20.8 \%$ were effectively profascist or virtual Nazi sympathizers. As bad as that sounds on the surface the data was less damning and gloomy than it appeared.

- There was a nearly $10 \%$ difference between workers in the AFL and the CIO with the latter being somewhat less prone to anti-Semitism. That difference was probably greater and more important when it came to the decisive question five that sought to locate the levels of violent worker hostility toward Jews and identifying with the Nazi program of extermination.

- Gender was an important variable in worker anti-Semitism of the most violent type. Only twelve women were sympathetic to the Nazi program of exterminating Jews. But when it came to less extreme and violent solutions (in response to the decisive question number five) women were not significantly different than their male counterparts.

- Young workers (up to age twenty-five) were very much less prone to anti-Semitism as their older counterparts. Only $3.5 \%$ of workers in this category condoned Nazi terror against Jews.

- Education had an important effect on decreasing violent anti-Semitism. Workers with only a grammar school education were almost three times more likely to identify with the Nazi plan to cleanse the world of Jews. And, interestingly, a high school diploma was virtually as good as college experience or a college diploma in reducing violent anti-Semitism. The major exception to this rule was among workers over the age of 50 with higher educations.

- Catholics were more likely than Protestants to embrace Nazi terror and it appeared that Catholics needed frequent church attendance more than Protestants to check their violent impulses toward Jews.

- "Nonreligious" workers were very similar to Protestant workers when it came to violent anti-Semitism.

- "Americanization" (the effect of American society on second and third generation workers) contributed significantly to decreasing hostility toward Jews. 
- Nationality or national origins was not a tremendously decisive variable in determining levels of violent antisemitism except in the case of workers with Scandinavian backgrounds. They were much less likely to identify with Nazi measures and workers with roots in Mexico were the most likely to identify with the total rejection of Nazi extermination. But generally, no nationality was exempt.

- The wages paid to a worker had little effect on their level of anti-Semitism. Higher wages did not reduce hostility toward Jews nor did low wages increase hostility.

- The difference between skilled and unskilled workers was not significant in reducing anti-Semitism.

- Occupational status did have a strong effect on anti-Semitism. Unlike the European context, American white-collar, professional, and clerical workers were much less likely to succumb to hatred of Jews. The Institute concluded that they were "resistant" and had "amazingly liberal attitudes" compared to their European and blue collar counterparts.

\section{Conclusion}

Slater argues that what Horkheimer and Adorno were up to during this period represented a "degeneration" of theory due to its lack of connection to capital accumulation (1977:87). But this was not true of the Institute as a whole. The kind of work being undertaken by the "Other Frankfurt School" (the "dispersed forces" as Massing once jokingly put it) represented the antithesis of Horkheimer's antidialectics. Gurland, Massing, and company were, by contrast, working out the problems of anti-Semitism and fascism all the way from the molecular level of lived experience in a commodity world up to the institutional forms of capitalist society. That they persevered and produced a massive, brilliant, nuanced, and multidimensional research report while combating both the growing irrationalism of the Horkheimer Circle and the inherent conservatism of their benefactors at the AJC is a testament to the power of moral seriousness and even optimism required of critical theory. "In 1935, Horkheimer asserted (and acknowledged) that the value of theory 'depends on its relation to praxis'. The socio-political consequence of this relation was that an adequate social theory had to be linked to the existing revolutionary forces within society..." (Slater 1977:15).

Upon arriving in the United States the Institute established a genuinely furious research pace and generated volume upon volume of analysis and findings rooted in solid empirical inquiry. If, as Habermas (1984) says, "Resignation had already set in by 1941" , by the mid-40s the Institute's theoretical perspective had become so contradictory, pessimistic, and irrational, that for all intents and purposes, critical theory collapsed (p. 64). "In 1946 the Institute had cut its links with Columbia University, at the very moment Columbia had wanted to intensify them at the end of the war." By 1947 the Anti-Semitism Project began to crumble and Horkheimer resigned from his position as research consultant at the American Jewish Committee; by 1948 the very concept of capitalism began to vanish from Horkheimer's vocabulary (Wiggershaus 1994:397-402). The last convulsion of the overall anti-Semitism program was the 1950 publication of The Authoritarian Personality. And that was that. Horkheimer and Adorno packed up and left for Germany.

During the 1960s and 1970s the work of the ISR was rediscovered by the New Left and campus radicals. But what was recovered as the "Frankfurt School" was but a one-sided caricature of the Institute. They had been deeply involved in studying the working classes but many American radicals had, as far back as the 1930s, been trying to replace "the workers" with "the people" or some other post-Marxist notion and the New Left was, in the words of Howard Zinn, a "loose amalgam of civil rights activists, Black Power advocates, ghetto organizers, student rebels, Vietnam protestors..." that had a lot more than the "working class" on its mind (quoted in Stolz 1971:36). Plus, the core research problems of the Frankfurt School were not carried over by the New Left. For example, the ISR's recurring analyses of anti-Semitism, what Zizek (2000) calls their "permanent obsession" was basically lost because, at least in the social sciences, the study of anti-Semitism had only a spectral existence (p. 157). With notable exceptions, on the few occasions that academic sociology has grappled with the problem it has done little more than embarrass itself. In short, the social science aspect of critical theory was left to rot as English departments and philosophy students transformed critical theory into a chic but disembodied discourse on instrumental rationality. Consequently, the ISR's profile was reconstituted within New Left belles-lettres as a slick if thorny rumination on the dialectics of reason that had, as Zizek (2000) puts it, the effect of "a fateful shift from concrete socio-political analysis to philosophicoanthropological generalisation, the shift by means of which the reifying 'instrumental reason' is no longer grounded in concrete capitalist social relations..." (p. 156). 


\section{Endnotes}

1. In the Institute's "Report on its History, Aims and Activities, 1933-1938" it is stated that "Even at the cost of reducing its own scientific activity, the Institute set aside considerable funds to help these people continue their work and thereby their intellectual existence. These funds were not given out as mere charity, but as grants for specific projects and studies. Not a few scientific works of émigré scholars have been completed and published thanks to this assistance, and valuable contributions in the tradition of German thought have thus been saved. Many of these studies were published in the cooperative volume Autorität und Familie or in the Zeitschrift für Sozialforschung. In other cases the Institute contributed to publication costs. Over 50 stipends, many of them running over a period of years, have been granted for that purpose since 1933" (1938:17).

2. Felix Weil, the man with the money, also had his own Latin American Economic Institute that shared offices with the ISR in New York City. The LAEI had a secretary of its own, letterhead, and released a few publications. The "inner circle" was constantly in flux as Horkheimer and Pollock sought to shed members deemed burdensome. Ultimately, of course, Lowenthal was also deemed expendable. By the mid 1940s Fromm was no longer employed as well as scorned for his revisionism (and perhaps his popularity); Marcuse "constantly in touch with Horkheimer...was held at a distance"; and Neumann, Grossmann, Kirchheimer, and Wittfogel, to varying degrees, simply evaporated from the scene over time, finding academic and government jobs (Wiggershaus 1994:383).

3. The ISR is commonly portrayed as (a) the cashstrapped organization needing to shed excess weight to stay afloat or (b) the charitable organization extending a lifeline to exile scholars. There is a truth to both of these accounts but there were funds coming into the Institute, and not just from the $\mathrm{AJC}$, that worked in several directions to complicate the story. The Emergency Committee In Aid of Displaced Foreign Scholars and, to a lesser extent, the Oberlaender Trust, both assisted the Institute's payroll. The Emergency Committee made grants on the condition that the recipients were also supported by the Institute such that their annual salaries equaled $\$ 4000$. Marcuse, for example, was already being paid $\$ 4200$ in 1940 so the Institute cut his salary in order to secure the additional, external funding. Other grants were awarded to Kirchheimer (four times), Neumann (twice), Massing (twice), Max Beck, and Zilsel. The Trust also awarded grants to Institute associates Max Beck and Ernst Bloch and former and future associates such as Kapp and Karsen. Kirchheimer was awarded $\$ 960$ by the Trust in 1940 (Worrell 2003, Appendix K; EC Series I, b24).

4. Equally important problems were Horkheimer's flight into orthodox psychoanalytic theory and the ISR's growing affinity for biological reductionism. These problems have been examined already by David
Norman Smith (1992). Moreover, there was a growing "entrepreneurial" posture vis-à-vis Institute members such that many of the people who breathed vitality into the empirical research streams of the Institute were subjected to a pioneering form of flexible labor practices that combined insecurity, contingent and short-term contracts, and paternalistic emotional manipulation. Wiggershaus (1994) sufficiently draws out these aspects. Marcuse was perhaps the idealtypical case. Horkheimer led Marcuse along: cutting his wages, dictating his place of residence, pushing him toward employment outside the Institute, while simultaneously leading him to believe that his future was at Horkheimer's side in the Institute (Wiggershaus 1994).

5. Even though the Institute's core members were not sympathetic to the Fourth International, the Horkheimer political odyssey was not dissimilar to that of, say, the Alcove One crowd at City University who made the improbable journey from Trotsky to Nixon. For Horkheimer's attitude toward the German antiwar movement and Vietnam see Wiggershaus (1994:62425).

6. Actually, Paul Massing, the on-again, off-again Institute associate, was as far as I know the first to come under scrutiny during March 1940 when the FBI received information that Massing was moving near a Pennsylvania shipyard for possible espionage and sabotage work as a Nazi agent. The file was closed but reopened in 1942 when both Paul and his wife Hede were (correctly) identified as GPU agents.

7. The Columbia informant was used as a tool in the ongoing war between Robert MacIver and Robert Lynd. On the struggle between MacIver and Lynd, and the situation of the ISR within that conflict, see Wheatland (2004b:76-78). The FBI informant, an individual possessing a working knowledge of the Institute, was listed in the FBI's files as one "Robert M"-historians would no doubt pay a king's ransom to know the identity of this person.

8. On the role of Gumperz in helping the Institute to relocate to the U.S. and his manipulation by Horkheimer see Wheatland (2004a).

9. NA, HUAC Executive Session Testimony, September 21, 1948, Massing, 9E3/5/22/1, Box 7.

10. By November 1942 the FBI considered Paul and Hede Massing to be "connected with the Russian Terror Apparatus of the GPU.... the Massings, although reported to have broken with the Comintern are not believed by the source of information to have severed actually their connections with the GPU" (FBI HM, 65-396 1bh).

11. The "Red Head Group" was not limited to these three people but the story goes beyond the scope of 
the present discussion. I explore the issue further in my article "Joseph Freeman and the Frankfurt School." This information, except for Paul Massing's code name, is contained in Weinstein and Vassiliev (2000) and is based on recently opened archives of the KGB and the National Security Agency's declassified files pertaining to the Venona Program carried out by the U.S. Army's Signal Intelligence Service from 1943 until 1980 (http://www.nsa.gov/venona); Vassiliev's notes on a 1948 memo by Anatoly Gorsky on compromised agents and spy networks in America; and the Library of Congress, cold war, anticommunist historian John Haynes.

12. And Horkheimer was not keeping a very low profile: he was trailed by the FBI on an auto trip to Los Angeles and his telegrams to the Institute were intercepted and subjected to futile decryption efforts by American intelligence.

13. More than a decade later, Gurland, then on the edge of destitution working as a freelance translator and ghostwriter in New York, would continue to feel Horkheimer's animosity. While attempting to secure a university position in Germany, Gurland sought letters of support from his former associates at the Institute but, whereas "Teddy had been more than willing to oblige...Maaax [sic] had put his foot downfor 'political' reasons" (OK, letter from Gurland to Kirchheimer dated April 1, 1958).

14. For more on the Weimar proletariat study, as well as related efforts such as the Marienthal study conducted by Jahoda, Lazarsfeld, and Zeisel (2002), see Smith (1998) and Worrell (2003).

15. Bahr (1984) has criticized the Institute's work on anti-Semitism and declared that its Critical Theory was a failure. Bahr, though, paints with broad strokes and claims that substantive borrowings from the labor study and the Berkeley group found their way into Dialectic of Enlightenment. Anyone who has read both the labor report and Adorno's chapters in Authoritarian Personality will be hard pressed to recognize more than a fleeting family resemblance.

16. See Jay (1980) for some insight into the emerging importance of anti-Semitism for the Institute's work. It should be noted, though, that Jay falls prey to received wisdom when he claims that "In their faithfulness to Marx's own attitude towards anti-Semitism, Horkheimer and his colleagues conformed to a pattern that many observers have noted: the more radical the Marxist, the less interested in the specificity of the Jewish question" (p. 138). In fact, the overwhelming majority of work done on anti-Semitism was performed by the most radical members of the Institute.

17. For a complete summary and analysis of the project's data and methods see Worrell (2003).

18. Martin Jay reports that the document delivered to the JLC in 1944 was 1300 pages in length ([1973] 1996:225) when in fact it was exactly 1449 pages in length and delivered in 1945. Jay also says that "After allowing the study to lie fallow for several years, renewed efforts were made in 1949. Paul Lazarsfeld and Allen Barton were recruited to write a methodological introduction" (ibid.). Actually, the report was handed over to Lazarsfeld's Bureau in 1947 and it was Seymour Fiddle who was tasked with writing a large summary and analysis of the entire project that is, in itself, very interesting and insightful. Unfortunately, the Fiddle report is beyond the scope of the present discussion except to say that it probably confirmed in Horkheimer's mind the fact that the sharp, critical edge of the report could not be blunted into inert liberal jargon. Jay claims that the findings of the labor report were made redundant by the Studies in Prejudice series (ibid.). This strikes me as incorrect. Indeed, the findings were unlike anything else the Institute produced and was the only project that could make an obvious claim to its neo-Marxist heritage. Jay claims that the labor study's methods were "primitive" compared "to the achievements of the various volume in the Studies in Prejudice" series (ibid.). This is very far from the truth. The project's methods were, in fact, groundbreaking and would serve sociologists well as a model to emulate (see Worrell 2003, Appendix D for a full analysis of the labor study methods). Jay claims that the labor study found that "More than half the workers surveyed had shown anti-Semitic bias of one sort or another..." (ibid.). The results were such that exactly half, not more not less, were afflicted by anti-Semitic feelings. Jay also perpetuates the myth that the labor project was a kind of precursor or "testing ground" to "latter studies" such as the Berkley project (op cit, p. 226). In fact, the labor study began two weeks after the Authoritarian Personality project; it was not a "testing ground" but the sister study.

\section{Abbreviations}

\begin{tabular}{|l|l|}
\hline AL & "Anti-Semitism among American Labor, 1944-45" (Unpublished report by the Institute of Social Research) \\
\hline "b/f” & Archival box and folder numbers \\
\hline BW & Bertram Wolfe Papers \\
\hline EC & Emergency Committee in Aid of Displaced Foreign Scholars \\
\hline
\end{tabular}




\begin{tabular}{|l|l|}
\hline FBI HE & Federal Bureau of Investigation, Freedom of Information/Privacy Acts Section, Hanns Eisler Files \\
\hline FBI HM & Federal Bureau of Investigation, Freedom of Information/Privacy Acts Section, Hede Massing Files \\
\hline FBI MH & Federal Bureau of Investigation, Freedom of Information/Privacy Acts Section, Max Horkheimer Files \\
\hline GH & Granville Hicks Papers, Syracuse University \\
\hline ISR & Institute of Social Research \\
\hline JF & Joseph Freeman Collection, Hoover Institute, Stanford University \\
\hline JLC & Jewish Labor Committee \\
\hline LL & Leo Lowenthal Papers, Houghton Library, Harvard University \\
\hline NA & National Archives \\
\hline NYPL & New York Public Library \\
\hline NYT & New York Times \\
\hline OK & Otto Kirchheimer Papers \\
\hline PH & Powers Hapgood Papers, Indiana University \\
\hline RB & Roger Baldwin Papers, Seeley G. Mudd Manuscript Library, Princeton University Library \\
\hline USP & Upton Sinclair Papers, Indiana University \\
\hline
\end{tabular}

\section{Archival Sources, Libraries, and Special Collections}

Bertram Wolfe Collection, Hoover Institution Archives, Stanford University

Bureau of Applied Social Research Archive, Columbia University Cleveland Public Library

Edward Earle Collection, Seeley G. Mudd Manuscript Library, Princeton University Library

Federal Bureau of Investigation, Department of Justice, Washington, D.C., (Freedom of Information Section).

Hanns Eisler Collection, Specialized Libraries and Archival Collections, Doheny Memorial Library, University of Southern California

Papers of the Emergency Committee for Displaced Foreign Scholars, Manuscripts and Archives Division, Humanities and Social Sciences Library, New York Public Library

Louis and Markoosha Fischer Papers, Seeley G. Mudd Manuscript Library, Princeton University Library

Ruth Fischer Papers, Houghton Library, Harvard University

Joseph Freeman Collection, Hoover Institution Archives, Stanford University

Mike Gold Papers, Labadie Collection, University Library, University of Michigan

Granville Hicks Papers, Department of Special Collections, Syracuse University Library
Powers Hapgood Papers, Manuscripts Department, Lilly Library, Indiana University

Institute of Pacific Relations Collection, Hoover Institution Archives, Stanford University

Horkheimer-Pollock Archives, Stadt Frankfurt am Main, Stadt und Universitatsbibliothek Frankfurt, Germany

The Kansas Collection, Spencer Research Library, University of Kansas

Otto Kirchheimer Papers, State University of New York, Albany

Karl Korsch Papers, International Instituut voor Sociale Geschiedenis, Amsterdam the Netherlands

Leo Lowenthal Papers, Houghton Library, Harvard University

National Archives, Records of the U.S. House of Representatives Record Group 233 House Un-American Activities Committee (HUAC), National Archives and Records Administration, Washington, DC

Henry Pachter Papers, State University of New York, Albany

Upton Sinclair Papers, Manuscripts Department, Lilly Library, Indiana University

Robert F. Wagner Labor Archives, New York University

\section{References}

Adorno, T.W., Else Frenkel-Brunswik, Daniel J. Levinson, and R. Nevitt Sanford. 1950. The Authoritarian Personality. New York: W.W. Norton and Co.

Bahr, Ehrhard. 1984. "The Anti-Semitism Studies of the Frankfurt School: The Failure of Critical Theory.” Pp. 311-21 in Foundations of the Frankfurt School of Social Research, edited by Judith Marcus and Zoltan Tar. New Brunswick: Transaction Books.
Brunkhorst, Hauke. 2000. "The Enlightenment Rationality: Remarks on Horkheimer and Adorno's Dialectic of Enlightenment." Constellations 7(1):133-40.

Dubiel, Helmut. [1978] 1985. Theory and Politics: Studies in the Development of Critical Theory. Translated by Benjamin Gregg. Cambridge: The MIT Press.

Fromm, Erich. 1984. The Working Class in Weimar Germany. Translated by Barbara Weinberger and edited by Wolfgang Bonss. Cambridge: Harvard University Press. 
Habermas, Jürgen. 1984. "The Frankfurt School in New York." Pp. 55-65 in Foundations of the Frankfurt School, edited by Judith Marcus and Zoltan Tar. New Brunswick: Transaction Books.

Honneth, Axel. 2000. "The Possibility of a Disclosing Critique of Society: The Dialectic of Enlightenment in Light of Current Debates in Social Criticism." Constellations 7(1):116-27.

Horkheimer, Max and Theodor W. Adorno. [1944] 1972. Dialectic of Enlightenment. New York: Continuum.

Institut für Sozialforschung. 1937. Authority and the Family: A Partial Translation of the Investigations by the International Institute of Social Research. Translated by A. Lissance. New York: State Department of Social Welfare and the Department of Social Science, Columbia University.

Institute of Social Research. 1945. "Ten Years on Morningside Heights: A Report on the Institute's History, 1934 to 1944. ."

-----. 1944-45. "Anti-Semitism Among American Labor: Report on a Research Project Conducted by the Institute of Social Research (Columbia University) in 1944-1945."

-.---. 1944. "Studies in Antisemitism: A Report on the Cooperative Project for the Study of Anti-Semitism for the Year Ending March 15, 1944, Jointly Sponsored by the American Jewish Committee and the Institute of Social Research."

----. 1943. "Project on Anti-Semitism and American Labor." December. Unpublished report presented to the AJC as part of the unpublished "Studies in Anti-Semitism".

International Institute of Social Research. 1938. "International Institute of Social Research: A Report on its History Aims and Activities, 1933-1938." New York: IISR.

Jahoda, Marie, Paul F. Lazarsfeld, and Hans Zeisel. 2002. Marienthal: The Sociography of an Unemployed Community. New Brunswick: Transaction Publishers.

Jay, Martin. 1980. "The Jews and the Frankfurt School: Critical Theory's Analysis of Anti-Semitism.” New German Critique 19(1):137-49.

Jay, Martin. [1973] 1996. The Dialectical Imagination. Berkeley: University of California Press.

Kellner, Doug. 1993. "Critical Theory Today: Revisiting the Classics." Theory, Culture and Society 10(2):43-60.
Lowenthal, Leo. 1987. False Prophets: Studies on Authoritarianism. New Brunswick: Transaction Books.

Scheuerman, Bill. 1994. "The Demise of the Early Frankfurt School: A Lost Document." Constellations 1(1):113-15.

Sherman, Charles B. 1945. Labor's Enemy: Anti-Semitism. New York: Pamphlet Press.

Slater, Phil. 1977. Origin and Significance of the Frankfurt School. London: Routledge and Kegan Paul.

Smith, David Norman. 1998. “The Ambivalent Worker." Social Thought and Research 21(1/2):35-83.

Smith, David Norman. 1992. "The Beloved Dictator: Adorno, Horkheimer, and the Critique of Domination." Current Perspectives in Social Theory 12:195-230.

Stolz, Matthew F., ed. 1971. Politics of the New Left. Beverly Hills: Glencoe Press.

Tar, Zoltán. 1984. "Introduction” Pp. 1-26 in Foundations of the Frankfurt School of Social Research, edited by Judith Marcus and Zoltan Tar. New Brunswick: Transaction Books.

Weinstein, Allen and Alexander Vassiliev. 2000. The Haunted Wood. New York: Modern Library.

Wheatland, Thomas. 2004a. "The Frankfurt School's Invitation from Columbia University: How the Horkheimer Circle Settled on Morningside Heights." German Politics and Society Fall, 22(3):1-32.

Wheatland, Thomas. 2004b. "Critical Theory on Morningside Heights: from Frankfurt Mandarins to Columbia Sociologists." German Politics and Society Winter, 22(4): 57-87.

Wiggershaus, Rolf. 1994. The Frankfurt School. Cambridge: The MIT Press.

Worrell, Mark P. 2003. "Dialectic of Solidarity: Labor, AntiSemitism, and the Frankfurt School." Ph.D.dissertation, University of Kansas, Lawrence, KS.

Worrell, Mark P. 1998. "Authoritarianism, Critical Theory, and Political Psychology: Past, Present, Future." Social Thought and Research 21(1/2): 3-33.

Zizek, Slavoj. 2000. "Postface: Georg Lukacs as the Philosopher of Leninism.” Pp. 151-182 in A Defense of History and Class Consciousness: Tailism and the Dialectic. London: Verso. 
